SCIREA Journal of Civil Engineering and

Building Construction

http://www.scirea.org/journal/CEBC

December 8, 2021

Volume 6, Issue 2, April 2021

https://doi.org/10.54647/cebc56065

\title{
Internal erosion vulnerability of core soil due to drought: Case study of three zoned dams
}

\author{
Ahmed Jalil ${ }^{1,2}$, Ahmed Benamar ${ }^{1 *}$, Mohamed Ebn Touhami ${ }^{2}$ \\ 1 LOMC UMR 6294 CNRS-University of Le Havre Normandie, Department of civil \\ Engineering, 53 rue de Prony 76600 Le Havre, France. \\ ${ }^{2}$ Laboratory of Materials and Environment Engineering, University of Ibn Tofail, B.P 242, \\ Kenitra, Morocco \\ * Corresponding Author, Email: ahmed.benamar@univ-lehavre.fr
}

\begin{abstract}
Very long dry seasons due to high temperature and decrease of rainfall rate, may threaten the stability of dams and dikes, and make them more sensitive to internal erosion. This vulnerability raises a question of how such hydraulic structures could behave after the degradation of soil properties. This research investigated the susceptibility of three zoned dams in Morocco to internal erosion, particularly after the dam's core soil was submitted to the drying effect due to the drought, causing desiccation. For this purpose, Hole Erosion Tests (HETs) carried out on core soils collected from the three dams aimed to assess their vulnerability to erosion after desiccation. The materials have been also analyzed in order to assess their suitability to dam construction using the usual engineering guidelines. The erosion results, analyzed through the erosion kinetics and soil resistance classification, showed an initial high resistance to internal erosion of tested soils, but the desiccation makes the core soils more vulnerable to erosion, especially for Mazer dam whose core soil is a lean clay. So,
\end{abstract}


the soil resistance degradation affected in a different way the three core soils. So, a drought phase may threat strongly the core resistance against erosion, leading to serious damage in dam stability when refilling occurs during floods.

Keywords: Internal erosion; Base soil; Drought; Desiccation; Zoned Dam.

\section{Introduction}

Internal erosion is the primary cause of failure and incidents of levees, dikes, and dams around the world. Flow through a hydraulic embankment or its foundation may cause particle detachment and their transport before washing out. Internal erosion is a complex phenomenon threatening many dikes and embankment dams and may initiate in the embankment due to a concentrated leak in transverse cracks, or in poor compacted or high permeability zones (Caldeira, 2019). Four internal erosion mechanisms can take place: concentrated leak, backward erosion, contact erosion, and suffusion (Hanson and Simon, 2001). The mechanics of internal erosion show that all these four types of internal erosion initiate at a critical gradient, confirming that initiation of internal erosion normally occurs when the reservoir water level is at or near its highest ever (ICOLD, 2013).

MacRobert et al. (2019) shown that when the proportion of erodible particles exceeded a higher critical finer fraction, coarser particles became dispersed, no longer forming a skeleton from which particles could erode, resulting in internal stability. The migration of fine particles depends mainly on physical properties of soil and seepage. Fine particle migration is interrupted in unconnected pores, causing pore blockage and fine particle accumulation, which then leads to the formation of a weak layer and further soil failure or collapses (Cui et al., 2017). Wilson et al. (2007) have shown that changing soil properties can have an impact on seepage erosion and can cause serious damage leading to the failure of hydraulic structures. Indraratna et al. (2011) developed a new empirical criterion for assessing the potential of internal erosion and suffusion of granular soils. This method considers the bimodal structure of a soil having a primary coarse fabric and loose finer particles based on the porosities influenced by the particle size distribution and the degree of compaction. Chang et al. (2013) showed that the hydraulic gradients initiated under compression stress conditions generally increase with the shear stress ratio and then decrease when the soil approaches shear failure. The increment is mainly caused by the decrease of soil porosity as the stress ratio increases. In 
recent years, drought events increase in frequency, severity, and duration due to global climate warming in many countries over the world. Consequently, soils experience significant water evaporation as well as volume shrinkage, resulting in severe damage to infrastructures (Cui et al., 2010). It was reported in literature Wan and Fell (2002); Lim (2006) have shown that the increase in initial water content (above the optimal value) generates an increase in the erosion index Ie, and therefore a better erosion resistance. However, the magnitude of this degradation of the resistance against internal erosion is dependent on the soil nature. Sherard (1953) noted that the plasticity and compaction water content are essential parts in erosion resistance. Overall investigated parameters affecting internal erosion initiation and its progress, the soil drying effect before seepage occurrence have not been widely investigated. Salari et al. (2018) showed that hydraulic fracturing is a main cause of initiating internal erosion in a high earth-rock fill dam, and being located on a steeply sloped narrow valley may cause significant stress transfer from core near the abutments.

Zeng et al. (2019) have investigated the effects of both interfacial friction and layer thickness on desiccation cracking behavior of soil, through a series of desiccation tests (under a constant temperature of $30{ }^{\circ} \mathrm{C}$ ), and they showed that the initiation and propagation of cracks occur at relatively high-water content ranging from $10 \%$ to $40 \%$ during drying. However, the intensity of soil cracking increases with increase in interfacial roughness or decrease in soil layer thickness. These results also confirm that the effects of interfacial friction and layer thickness on soil desiccation cracking are coupled. Desiccation cracks resulting from water loss and volume shrinkage have a great influence on the mechanical and the hydraulic properties of soils, by weakening soil strength and causing slope instability and likely dikes failure Zeng et al. (2019). Archer and $\mathrm{Ng}$ (2018) proved that temperature and relative humidity influenced the behavior of a clay embankment through centrifuge modelling (thermal expansion of the soil). Moreover, cracks in liners can result in a drastic increase in hydraulic conductivity of soils. Thus, drying-induced shrinkage and desiccation cracking are important concerns in the design and analysis of soil structures for various geotechnical engineering applications under severe conditions due to global climate warming. Soil shrinkage could affect the susceptibility to internal erosion of earth embankments and clayey cores. Due to climate change, long heat seasons raised in the last decade in North Africa. Therefore, many hydraulic structures (dams and levees) might suffer shrinkage and desiccation, which could affect the resistance of hydraulic structures against internal erosion. This paper presents the investigation of the effect 
of drying-induced shrinkage and desiccation, resulted from long dry seasons and rainfall shortage, on the vulnerability to internal erosion of three zoned dams in Morocco.

\section{Climate impact on the area of studied dams}

Long drought, as recorded during the last decades in north Africa may impact drastically the safety operation of dams and dikes by reducing their resistance to internal erosion. The vulnerability of these hydraulic structures may lead to the degradation of soil resistance and then can affect their stability and durability. In the investigation area of Koudiat El Garn, Mazer and Moulay Boucheta dams, the rainfall data (Figure 1) from the last decade indicated that this area have experienced a long drought which let to emptying two dam reservoirs, drying deeply the earthen dike and causing cracks that may be increased over time. Cracks spread typically from the soil surface downwards through the drying surface, where the matrix suctions are usually the most significant, and the constraints due to self-weight are minimal (Morris et al., 1992). The Koudiat El Garn reservoir is empty (Figure 2a) whereas the reservoirs of Mazer and Moulay Boucheta dams are below 20\% of their total capacity (Figures. 2a and 2b) due to a drought period that has struck north Africa. Lowering reservoir levels beyond the current level would decrease the structural reliability of the intake structure. Most of the time, these embankment's dams are only submitted to low hydraulic heads and remain largely unsaturated (Dyer et al., 2007); Marnette et al., 2005), which is not going to threaten their stability that much either. However, during flood events embankment's dams need to withstand a rapid rise in water level on the outward face, along with the corresponding changes to pore water pressure (and potential seepage). Therefore, a new filling of the dam reservoir may lead to more susceptibility to internal erosion of core soil, especially after a flood event. The influence of surface desiccation on core vulnerability to internal erosion is one of the many uncertainties concerning the changes in physical processes and the trigger points of dam vulnerability in response to climate change (Dijkstra, 2004). The dryinginduced soil desiccation effect on soil susceptibility to internal erosion has been investigated in this study through Hole Erosion Tests of core soil from three dams. 


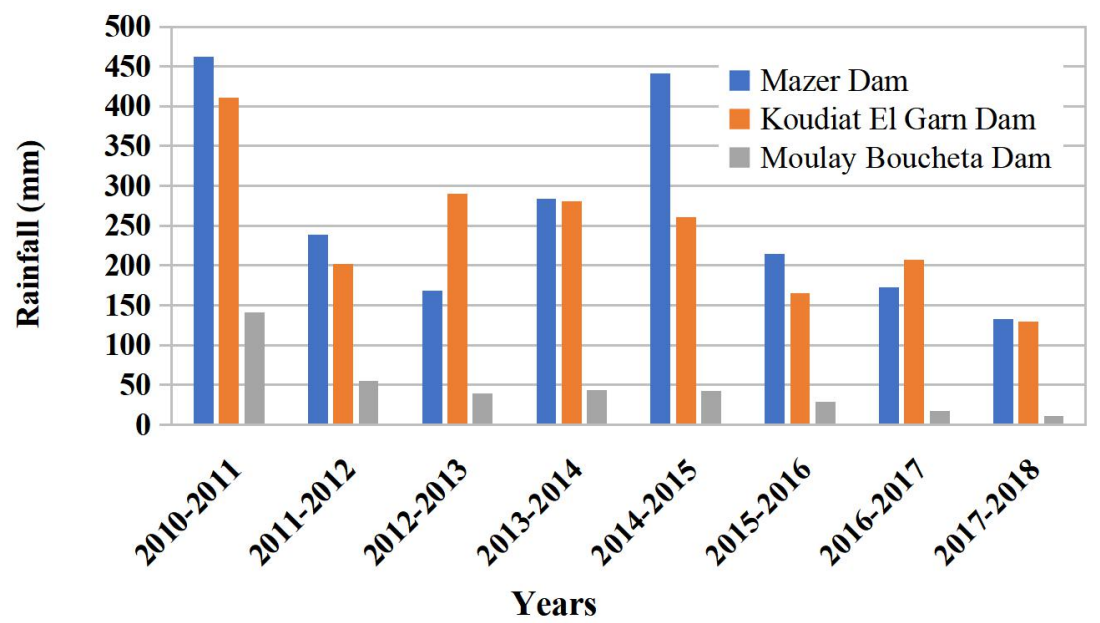

Figure 1. Evolution of the rainfall in the area of dam's location during the last decade
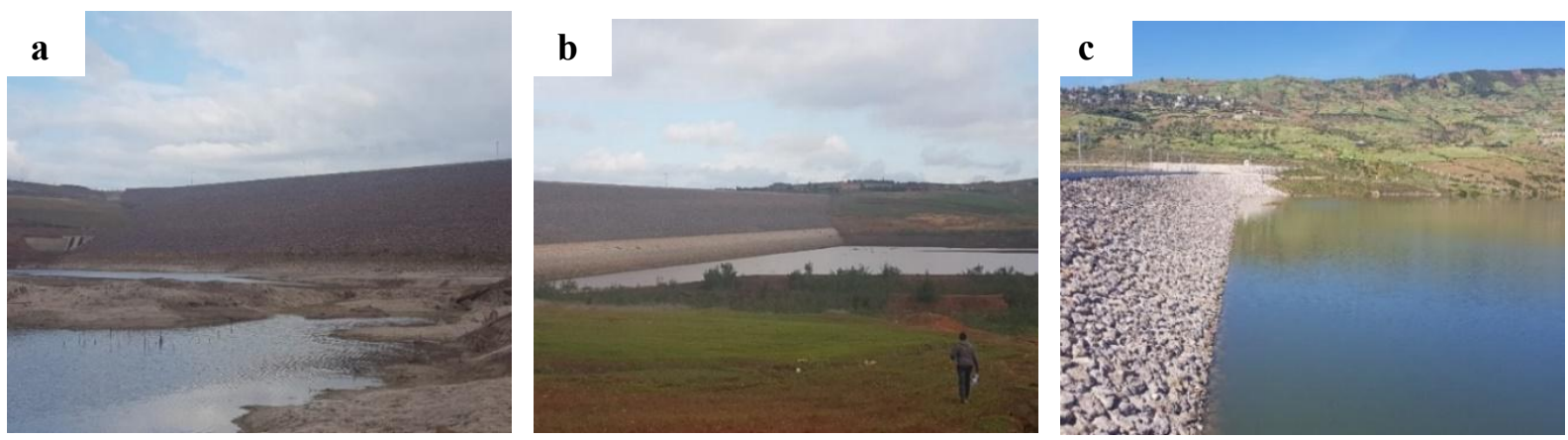

Figure 2. Pictures of the dam's reservoirs: (a) Koudiat El Garn, (b) Mazer, (c) Moulay Boucheta

(December 2016)

\section{Materials and test procedure}

\subsection{Dam's description}

After the strong floods which affected the region of Settat-Berrechid (Morocco) in 2002 and their damages caused on industrial and agricultural fields, the arrangement program of Koudiat El Garn and Mazer's dams and the warning system against floods were designed for the floodplain preservation. Mazer dam and Koudiat El Garn dam started operating in 2011 and 2012, respectively. The site of Moulay Boucheta dam is located about $12 \mathrm{~km}$ northwest of the city of Chefchaouene (on the main road connecting Chefchaouene to Tetouan), and was put into operation in 2014. Besides the flood prevention, the aim of these three zoned dams is also to guarantee irrigation of the lands located downstream, ensure the groundwater supply, 
and drinking water supply.

These three-zoned dams include mainly a central core, a filter, upstream and downstream embankments and protections (Figure 3).
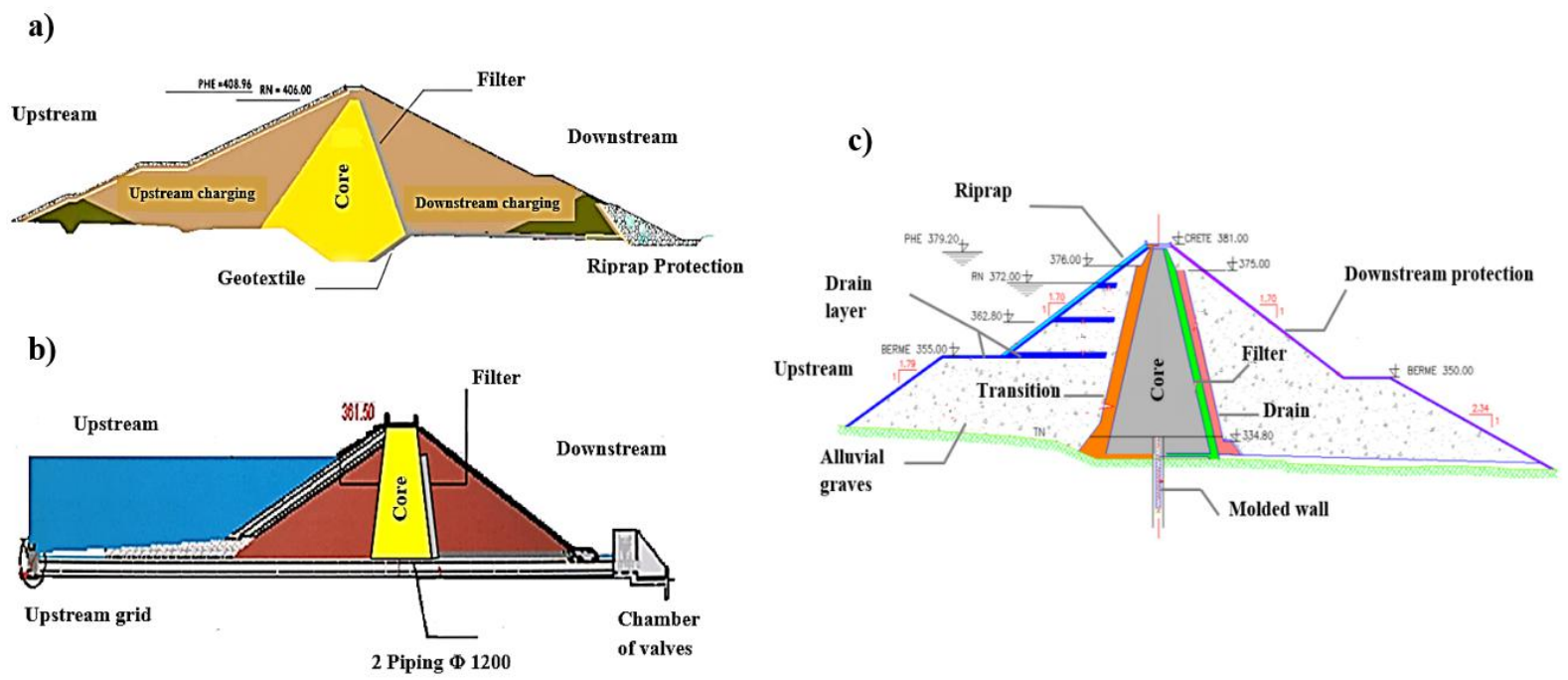

Figure 3. Cross-section views of the dykes of (a) Koudiat El Garn dam, (b) Mazer dam, and (c)

\section{Moulay Boucheta dam}

\subsection{Materials}

The core materials were collected from borrowings located in the areas of the reservoir from each of the three dams (Koudiat El Garn, Mazer, Moulay Boucheta). The particle size distributions obtained using a multisizer device (Malvern Corp) showed (Figure 4) a quite similarity between Koudiat El Garn and Mazer core soils, whereas Moulay Boucheta dam provided a finer core soil. The soil classification (ASTM D2487-17, 2017) indicates that the two core soils from Mazer and Moulay Boucheta dams are fat clay material whereas Koudiat El Garn core soil is a lean clay material. From soils analysis, Table 1 below summarizes the geotechnical parameters of tested materials. The core soils were compacted at close values of water content and density, but Moulay Boucheta dam core involved the most important plasticity (owing to its greater fines content). The preparation and the homogenization of materials according to water content and compaction have been achieved following the same conditions as those of the works currently under operation. The samples have been compacted on the wet side of the optimal water content and desiccation was later achieved by drying the sample up to target moisture for each core soil from the three dams. 


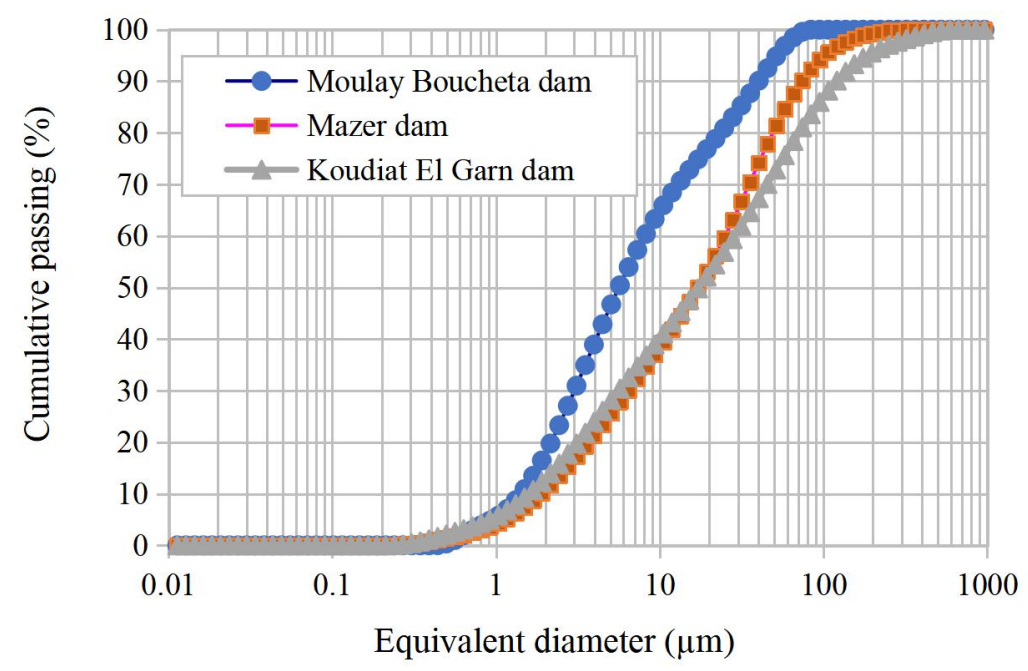

a)
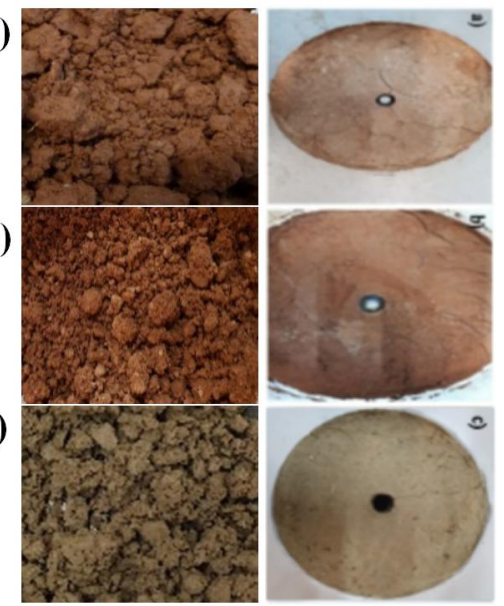

Figure 4. Particle distributions of core soils and soils pictures before compaction and after desiccation from (a) Koudiat El Garn, (b) Mazer and (c) Moulay Boucheta dams

Table 1. Soils (core) characteristics

\begin{tabular}{lccc}
\hline Soil dam & Koudiat El Garn & Mazer & Moulay Boucheta \\
\hline Classification $($ ASTM) & Lean Clay with sand & Fat Clay & Fat Clay \\
clay $(<2 \mu \mathrm{m})((\%)$ & 14.0 & 11.8 & 19.7 \\
Silt $(2$ to $63 \mu \mathrm{m})(\%)$ & 64.4 & 75.8 & 78.8 \\
Sand $(63$ to $2000 \mu \mathrm{m})(\%)$ & 21.6 & 12.4 & 1.5 \\
Fines $(<75 \mu \mathrm{m})$ content $(\%)$ & 81 & 90 & 99 \\
Water content $(\%)$ & 18 & 19 & 20 \\
Liquid Limit $(\%)$ & 48 & 53 & 53 \\
Plastic Index $(\%)$ & 23 & 25 & 32 \\
Dry density $\gamma(\mathrm{kN} / \mathrm{m} 3)$ & 17 & 17 & 17 \\
\hline
\end{tabular}

\subsection{Experimental set up and test procedure}

The test apparatus included a cylindrical plexiglass column of $140 \mathrm{~mm}$ inner diameter and $300 \mathrm{~mm}$ of length, a graduated water tank, a pump, and a pressure sensor at the inlet of the cell used to control the applied water pressure. The cell was connected to a water supply which provides a selected pressure in a range from $100 \mathrm{kPa}$ to $250 \mathrm{kPa}$.

The soil specimen was placed in the column in a vertical position by layer compaction in order to reach the target density. The soil specimen was $25 \mathrm{~mm}$ of width and $140 \mathrm{~mm}$ of diameter and was supported by a metal grid. A $15 \mathrm{~mm}$ diameter pinhole was drilled through both the specimen and the grid center (Figure 5) in order to induce a concentrated flow. The 
upstream remaining volume of the column was filled with glass beads to ensure a homogeneous distribution of the flow. Once the specimen of core soil was placed in the column, soil saturation has been performed under a low hydraulic load in order to not disturb the porous medium before the start of the test. A convergent device was placed at the bottom of the column in order to recover all detached particles and drive them toward the outlet. The column outlet was directed to a downstream flow meter and then to a turbidity meter whose recordings were previously correlated to particle concentration. Once saturation was achieved, the inlet pressure was increased rapidly to the target value.

a)

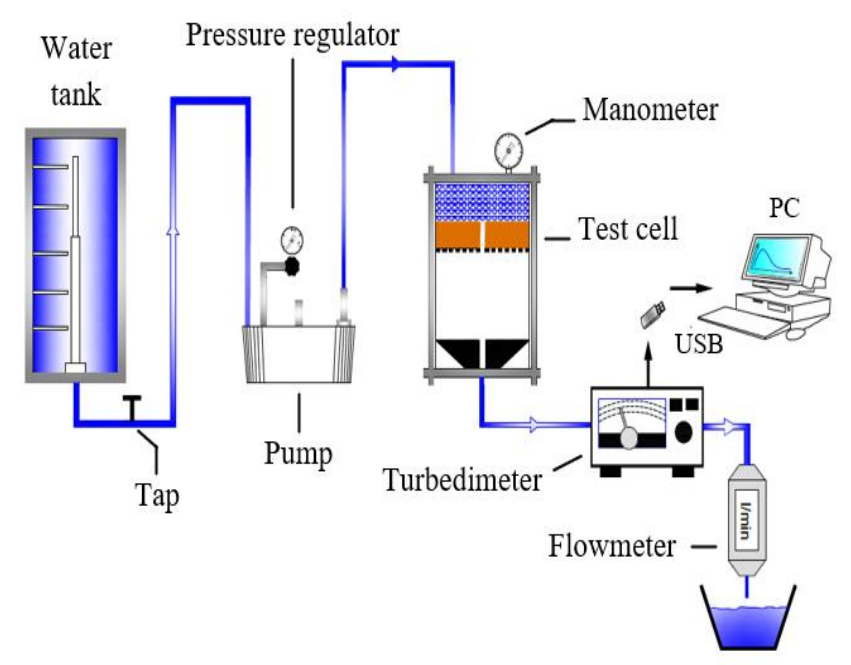

Recipient (recovered fines) b)

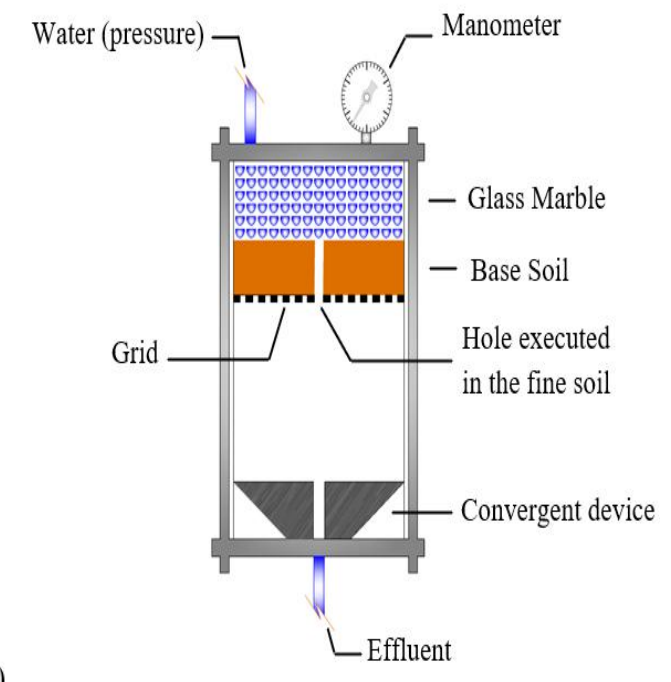

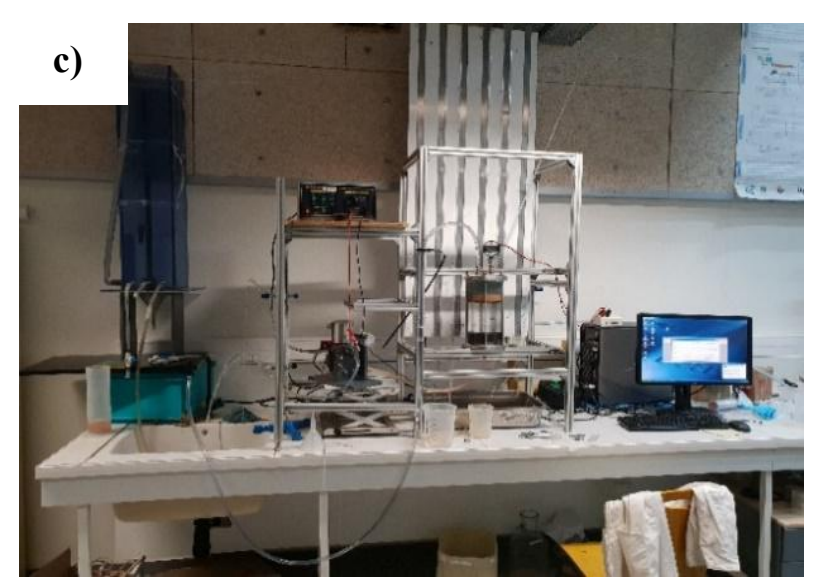

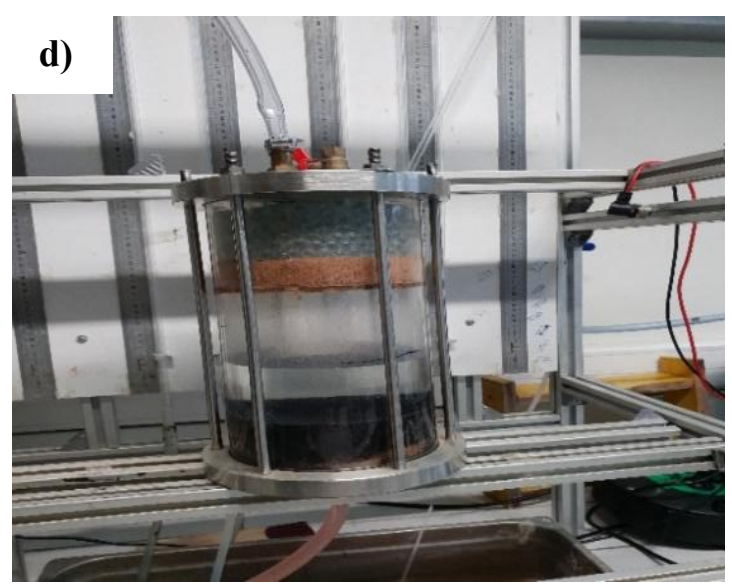

Figure 5. View of (a) schematic diagram of the experimental set up for hole erosion test, (b) detailed view of test cell, (c) overview of the set up, and (d) view of test cell in saturation phase (d)

The principle of the HET is to introduce a controlled seepage in a preformed cylindrical longitudinal pipe drilled through the soil specimen and to measure the erosion kinetics, aimed to evaluate the core soil erodibility at different hydraulic loads (pressures), before and after 
desiccation. The hydraulic shear stress generated at the soil / water interface then causes soil erosion within the conduit. The experimental process includes recording of the diameter increase of the pipe during test and measuring different parameters like: i) the water flow rate, ii) the pressure differential between upstream and downstream of the cell, and iii) the concentration of soil particles in the effluent (Jalil et al., 2021).

For each core soil, four successive pressure steps $(100,150,200,250 \mathrm{kPa})$ were applied and the erodibility was evaluated at each step. This experimental work aimed at investigating the behavior of soils with regard to the initiation and progression of internal erosion before and after desiccation, by the evaluation of the effect of the hydraulic (pressure load), the geometric (nature and proportion of fines) and the geotechnical (water content) parameters. In this part of the experimental program carried out, only erosion tests performed using two values of water content (before and after desiccation), are reported. Sample desiccation has been obtained by drying the material, simulating drought periods and reservoir emptying. This is likely to happen, knowing the risk of drought in dam's areas. However, during floods events and the subsequent quick rise of water level in the reservoir, and cracks induced abruptly by drought period (on the core soil) may lead dam embankment to become susceptible to internal erosion. Therefore, through these tests, we will be able to estimate the resistance ability against erosion of the base soil constituting the dam core and its behavior at optimum water content and after the severe decrease of water content (until the desiccation). Results analysis will allow to assess the core soil vulnerability against erosion and to evaluate the dam sustainability. Table 2 below summarizes the tests conditions with regards to soil parameters and applied pressure.

Table 2. Test parameters before and after desiccation

\begin{tabular}{l|lccc}
\hline \multicolumn{2}{l}{ Dam's base soil } & Koudiat El Garn & Mazer & Moulay Boucheta \\
\hline & Before drying & 18 & 19 & 20 \\
& 4.5 & 4.0 & 5.0 \\
\hline Hole diameter $(\mathrm{mm})$ & $100-150-200-250$ \\
\hline Applied pressure $(\mathrm{kPa})$ & \multicolumn{3}{c}{150} \\
\hline
\end{tabular}




\section{Results}

\subsection{Desiccation effect on core soil erodibility}

The recorded turbidity values during test at outlet led to derive through the correlation function the outlet particle concentration. Using flow rate recordings, the erosion kinetics was deduced as the product of particle concentration and flow rate. The drawn curves from Figure 6 showed the evolution of erosion kinetics over time, for both tests carried out before and after desiccation, for the three core soils. Overall, the erosion kinetics reached a maximal value rapidly before falling to a residual value, except for Mazer and Moulay Boucheta dams whose data remained at a very low constant value over the time. The results clearly showed how flow caused by a pressure lesser than $100 \mathrm{kPa}$ causes particle detachment from the hole surface. The erosion kinetics before desiccation remained low for the three dams, but increased considerably after desiccation, especially for Koudiat El Garn and Mazer dams (Figures. $6 \mathrm{~b}$ and $6 \mathrm{~d}$ ). Mazer dam appeared to be the most suffering internal erosion after desiccation as the erosion kinetics reached a very high value $\left(210^{3}\right.$ times the value before desiccation). This shows the effect of desiccation on the large detachment of particles and on the soil susceptibility against internal erosion (a quick particle erosion has been observed during the saturation phase before the test after desiccation especially for Mazer dam). Therefore, this result proves that more dryer was the core soil, more it became susceptible to erosion (Jalil et al., 2019; 2020), which promotes the detachment of particles much more quickly. However, it has also been found that erosion susceptibility differs from one dam to another either before or after desiccation. Mazer and Moulay Boucheta dams were the most resistant to erosion before desiccation, while after desiccation Mazer dam became the less resistant and Moulay Boucheta dam being the most resistant against internal erosion. So, even though a core dam was well designed to be resistant to erosion, after desiccation it can suffer a drastic susceptibility to erosion. That is the case of Mazer dam whose core soil showed the lower clay content and a significant silt content which likely contributed to the easy detachment of silty particles after a strong drying (Jalil et al., 2019; 2020). 
a)

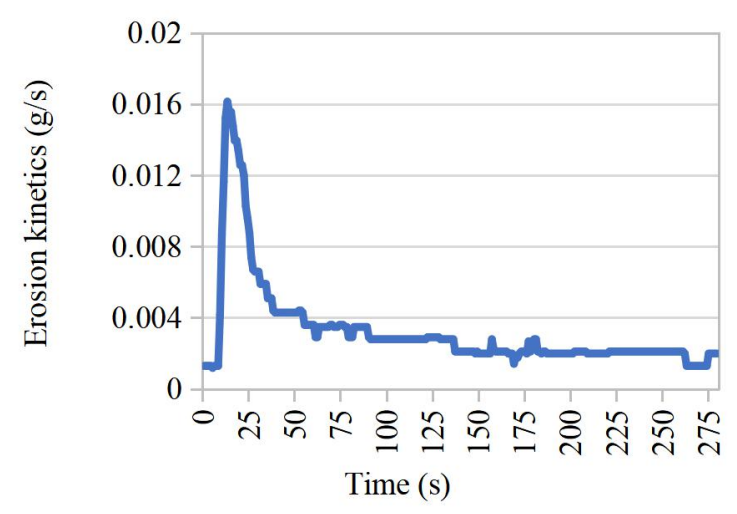

c)

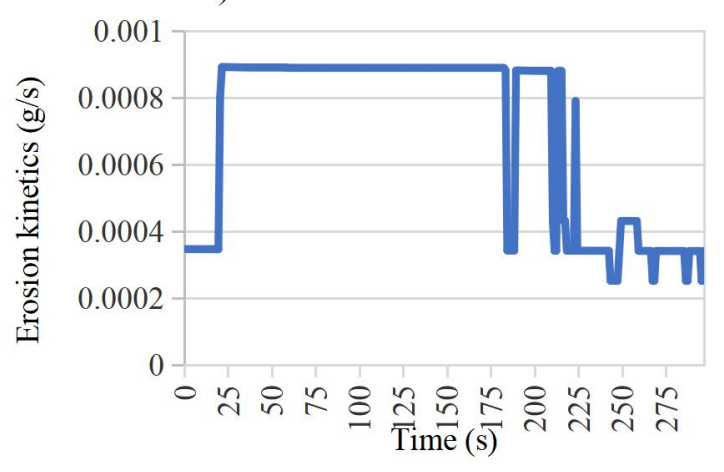

e)

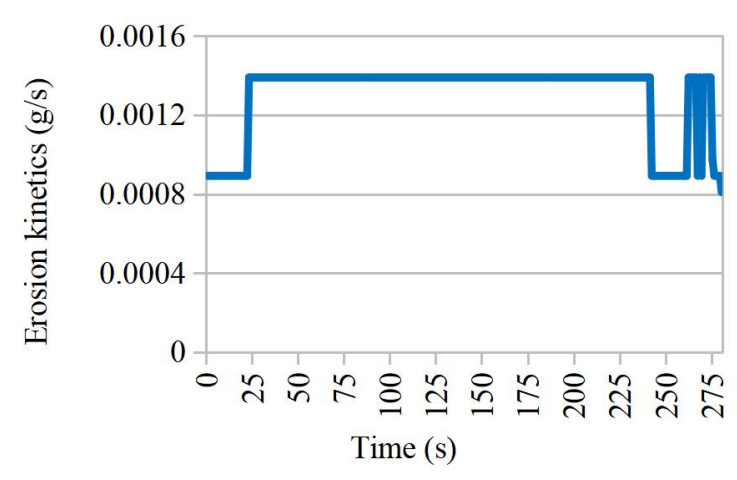

b)

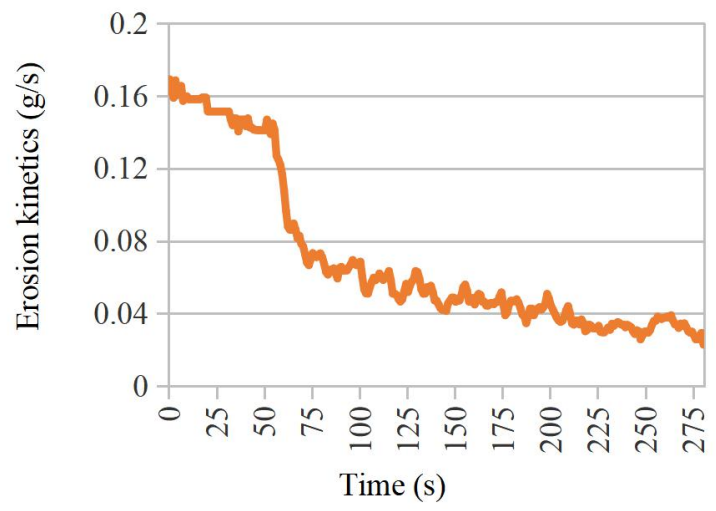

d)

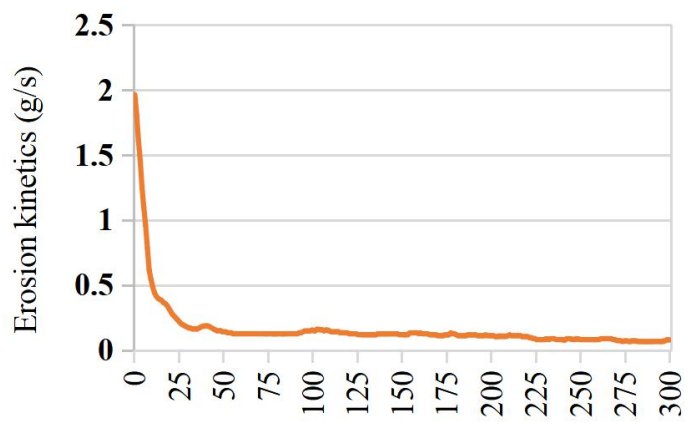

Time (s)

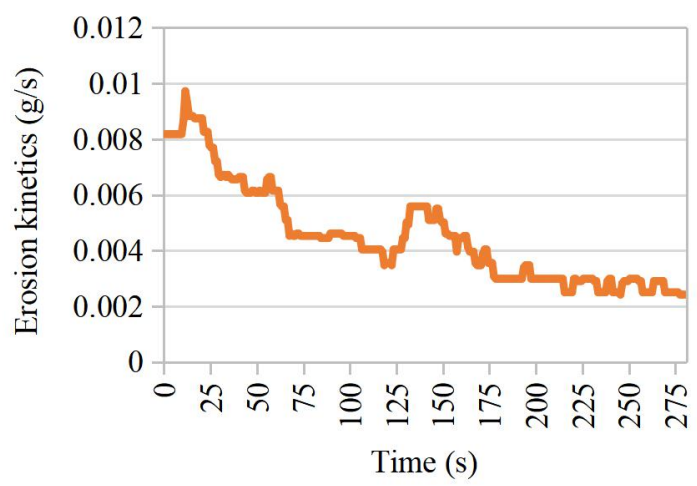

Figure 6. Time evolution of erosion kinetics in base soil at a pressure of $100 \mathrm{kPa}$ before desiccation (a, $c, e)$ and after desiccation $(b, d, f)$

\subsection{Effect of hydraulic head on erosion kinetics}

The susceptibility against internal erosion was usually investigated through erosion rate when hydraulic shear stress was increased. The second parameter which contributes to the erosion magnitude is the flow rate (or hydraulic conductivity) which leads to evaluate the eroded soil mass as the product of erosion kinetics and flow rate. From the analysis of the cumulated 
eroded solid mass (Figures. 7b, 8b, 9b) before and after desiccation, under successive applied pressures, results indicated that core soils before desiccation has undergone extremely slow erosion, except for Moulay Boucheta dam. The actual hole radius value after each pressure step was obtained from the eroded soil volume (eroded mass / dry unit mass), assuming a uniform enlargement of the hole along the pipe. Figures 7a, 8a, 9a shows the hole enlargement (from initial radius of $1.5 \mathrm{~mm}$ ) with increasing applied pressure. There was a slight hole enlargement for Koudiat El Garn and Mazer dams before desiccation whereas a large radius increase occurred after desiccation since the core soils were more susceptible to erosion after drying (as the water content decreased from $20 \%$ up to $4 \%$ and $4.5 \%$, respectively). But Moulay-Boucheta core soil remained less sensitive to erosion after drying (as the water content decreased from $20 \%$ up to $5 \%$ ) since a very low hole enlargement was recorded. Koudiat El-Garn dam showed a singular behavior as regards to desiccation effect, since the applied low pressure $(100 \mathrm{kPa})$ causes a very large erosion amount and no significant eroded mass was recorded under the further successive higher pressures. As regards to the influence of applied pressure, there was not a clear trend since after desiccation, the eroded mass globally decreased when pressure was increased for Mazer dam, whereas an opposite behavior was obtained (with pressures of 100 and $150 \mathrm{kPa}$ ) for Moulay-Boucheta dam. Overall testing conditions, the summarized results of cumulated eroded mass (Figure 10) indicated how the eroded solid mass was very less at initial moisture and became very important after drying and desiccation for the three studied dams. Even though Mazer soil core suffered the weakest erosion before drying, it provided the most susceptibility to erosion after desiccation. Similarly, Koudiat El-Garn dam showed a susceptibility to the desiccation effect, as well as Mazer dam, owing likely to the lower clay content involved and the weak soil plasticity. Moulay-Boucheta core soil was the most resistant against erosion after desiccation owing to its high plasticity and larger fines content. The arise of large erosion after drying when the first pressure step $(100 \mathrm{kPa})$ was applied is due to the availability of erodible particles in the desiccated depth of the specimen.

The desiccation effect on specimen shape was illustrated on Figure 11 (before and after desiccation) for the three dams in which pictures illustrated the shape of the hole after test for the two kinds of soil moistures. The cracks appearing after drying will affect the soil stability (Coulson, 2003; Dickson, 2004), particularly for Mazer dam. Taking into account the important quantity of cumulated eroded mass along the test, leading to the diameter enlargement of the hole over time (Fig. 11b), the picture illustrating the shape of the hole was 
in accordance with measured erosion kinetics.

\section{Koudiat-El-Garn dam}
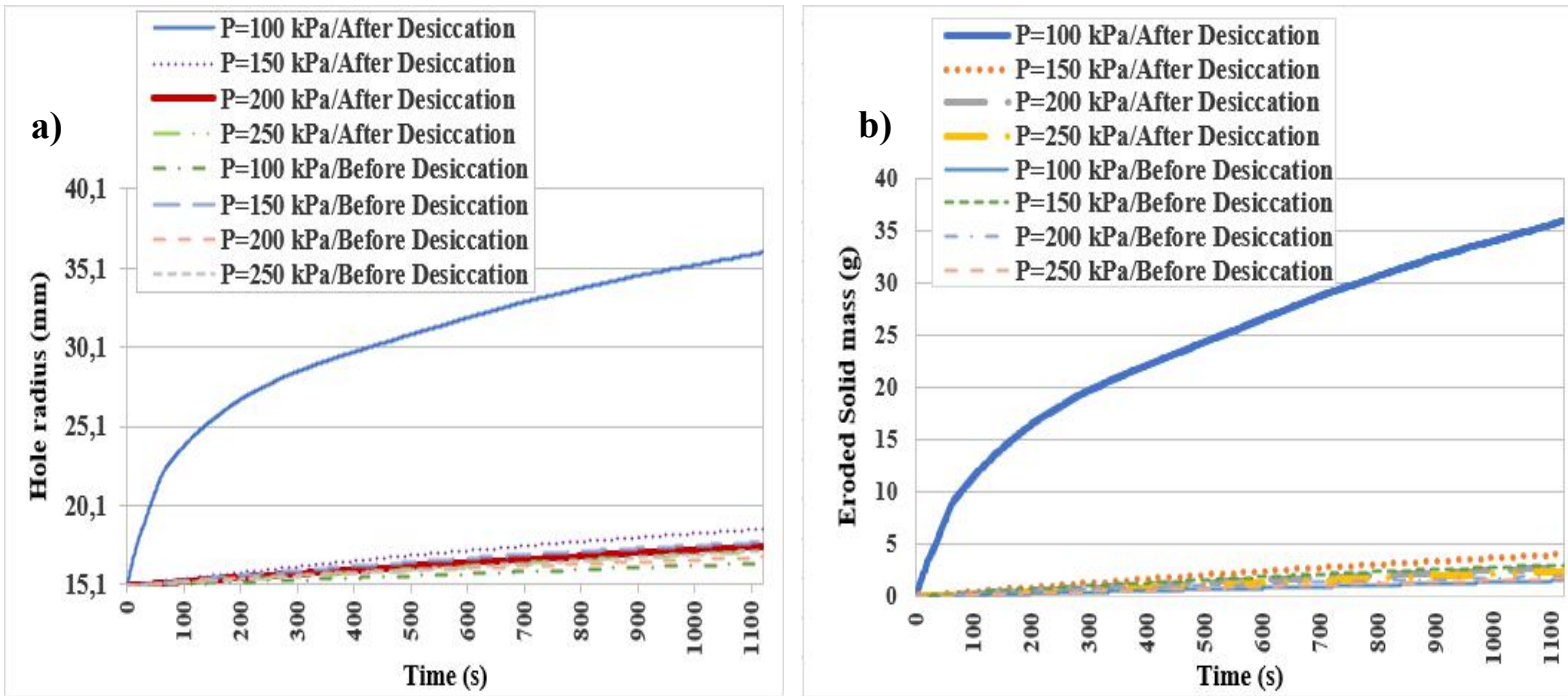

Figure 7. Evolution of (a) the hole radius, and (b) eroded solid mass with applied pressure before and after desiccation

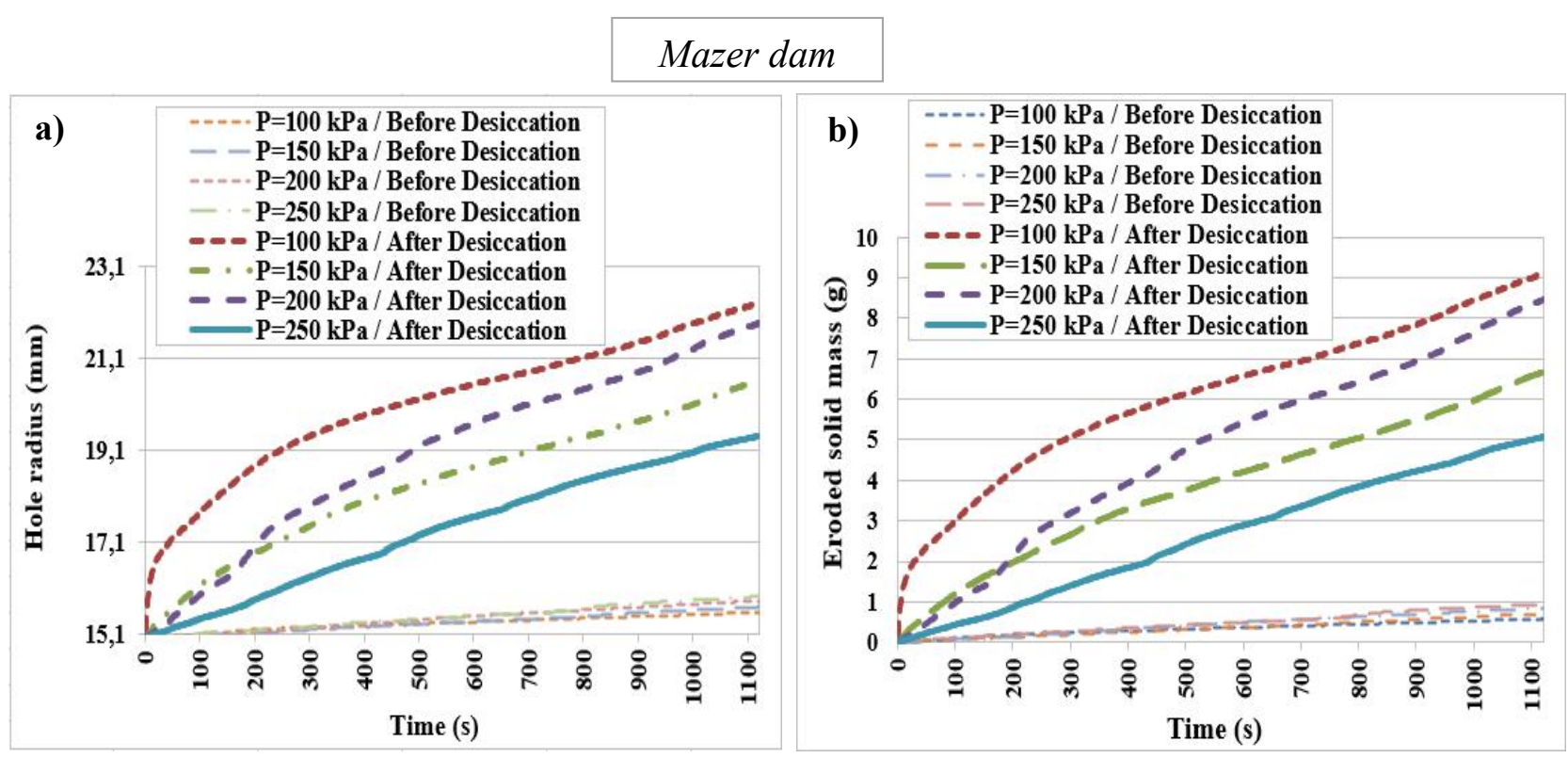

Figure 8. Evolution of (a) the hole radius, and (b) eroded solid mass with applied pressure before and after desiccation. 


\section{Moulay Boucheta dam}
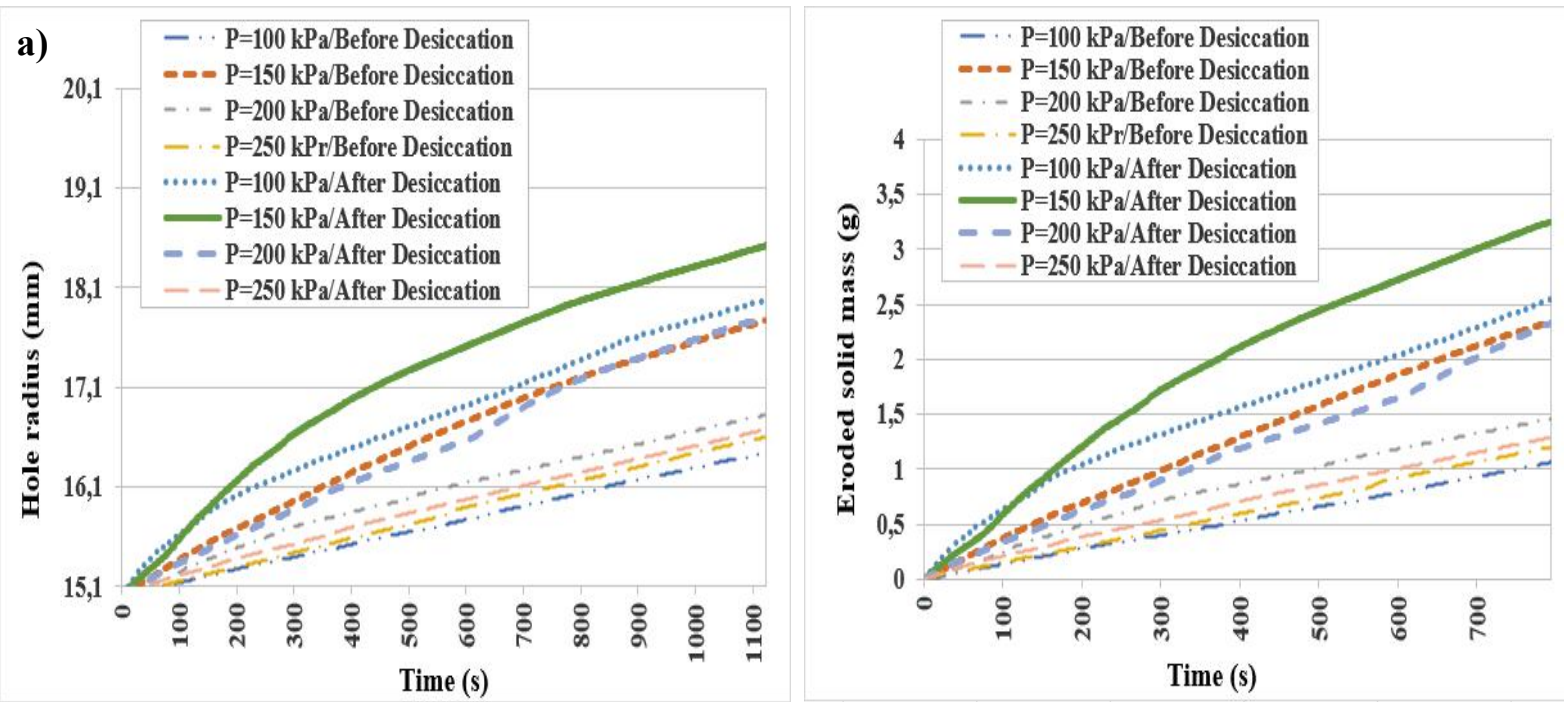

Figure 9. Evolution of (a) the hole radius, and (b) eroded solid mass with applied pressure before and after desiccation

a)

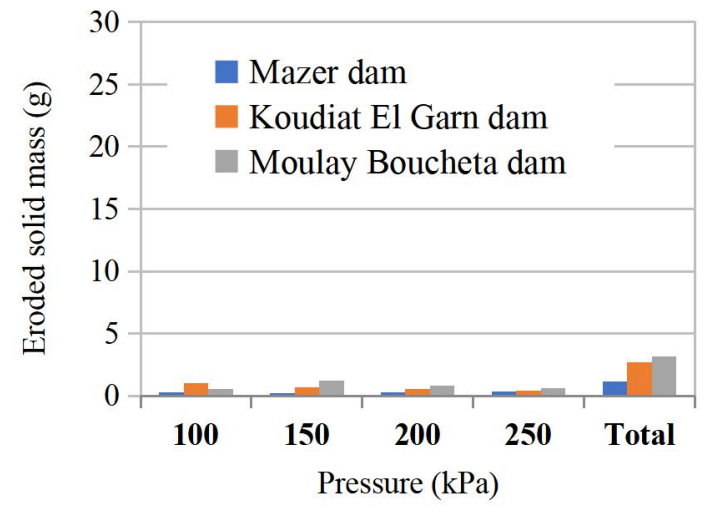

b)

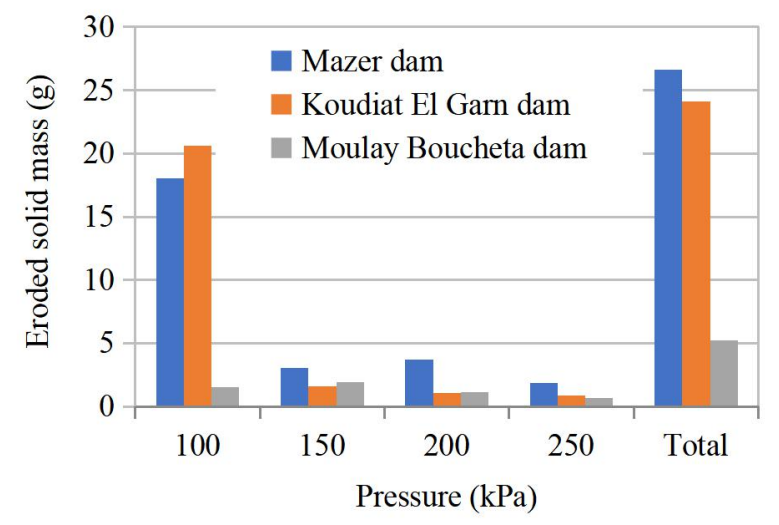

Figure 10. Evolution of cumulated eroded solid mass with applied pressure (a) before desiccation, and (b) after desiccation 

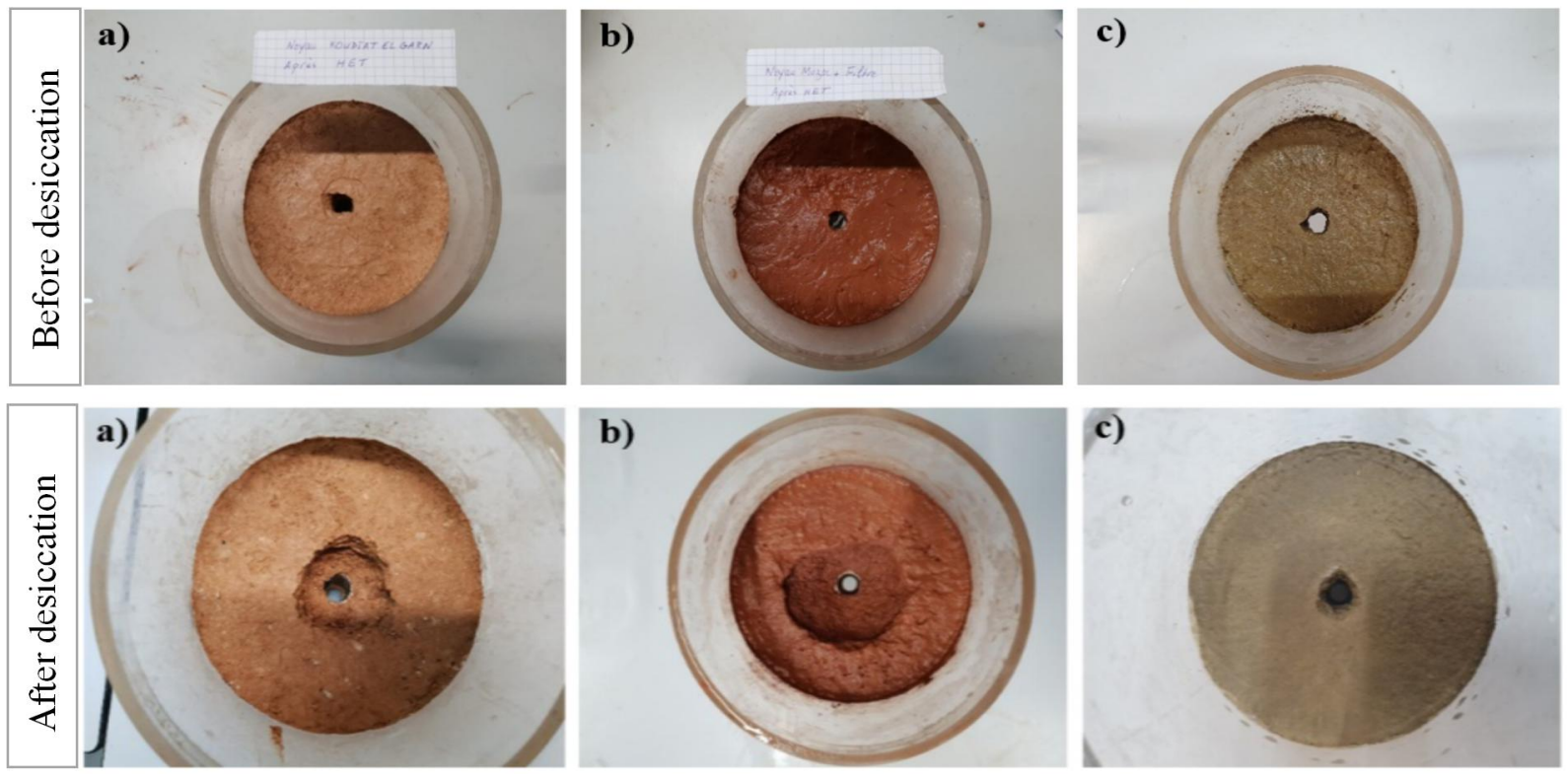

Figure 11. Pictures of the hole shape at the end of erosion test, before and after desiccation from (a) Koudiat El Garn, (b) Mazer and, (c) Moulay Boucheta dams

\subsection{Assessment of soil vulnerability to internal erosion}

In order to evaluate how desiccation can affect the resistance quality of soils against erosion, engineering guidelines were used to achieve the classification of each core soil before and after desiccation. Such vulnerability assessment was based on the guidelines suggested by Wan and Fell (2002), and Hansan and Simon (2001). The linear model from Reddi et al. (2000) was used to derive erosion kinetics parameters (erosion coefficient and critical shear) required in used guidelines. The evolution of erosion rate $\varepsilon$ versus applied shear stress $\tau$ (derived from applied pressure) is showed on Figures. 12 and 13. The linear regression obtained with experimental data provided good fits and the erosion coefficient $\mathrm{C}_{\mathrm{e}}$ (regression line slope) and the critical shear stress $\tau_{\mathrm{c}}$ (extrapolated shear value at zero erosion rate) were deduced and reported in Table 3.
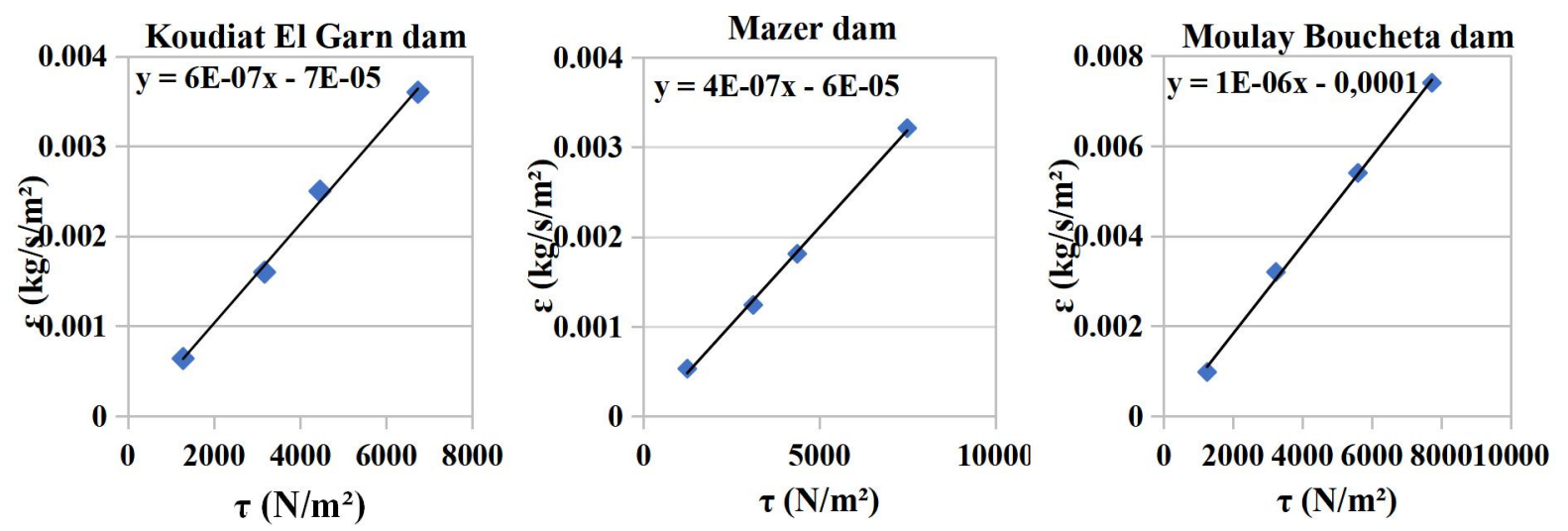

Figure 12. Evolution of erosion rate with applied shear stress before desiccation 

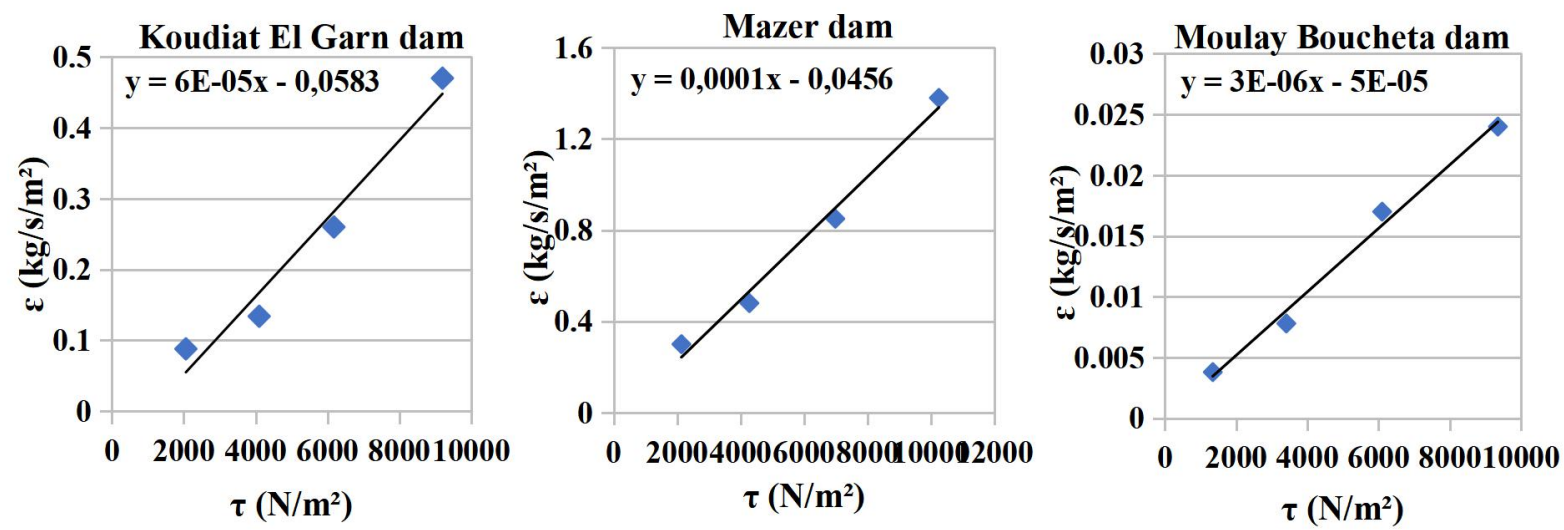

Figure 13. Evolution of erosion rate with applied shear stress after desiccation

All parameters which allow the characterization of the soil resistance to erosion and the comparison between core soils, are summarized on Table 3, where $\mathrm{I}_{\mathrm{e}}=-\log \mathrm{C}_{\mathrm{e}}$ is the erosion index, and $K_{d}=C_{e} / \rho_{d}$ is the erosion coefficient according to G. Hansan (2001). These values will be used for further classification of tested soils according to usual dam engineering guidelines. The critical shear stress value $\tau \mathrm{c}$ has been obtained by extrapolating the linear relation to zero erosion. The value of $\tau$ c for soil after desiccation was too low that it has been deducted from test performed at the lowest hydraulic load $(0.6 \mathrm{kPa})$ when erosion starts.

Table 3. Erosion parameters of tested core soils before and after desiccation.

\begin{tabular}{lcc}
\hline Designation of test & Before desiccation & After desiccation \\
\hline Koudiat el Garn dam & & \\
\hline$\tau_{\mathrm{c}}[\mathrm{Pa}]$ & 117 & 11 \\
$\mathrm{C}_{\mathrm{e}}[\mathrm{s} / \mathrm{m}]$ & $0.6^{*} 10^{-6}$ & $0.6^{*} 10^{-4}$ \\
$\mathrm{I}_{\mathrm{e}}$ & 6.2 & 4.2 \\
$\rho_{\mathrm{d}}\left[\mathrm{kg} / \mathrm{m}^{3}\right]$ & 1700 & 1700 \\
$\mathrm{~K}_{\mathrm{d}}[\mathrm{cm} / \mathrm{N} . \mathrm{s}]$ & $3.5^{*} 10^{-4}$ & $3.5^{*} 10^{-2}$ \\
\hline $\mathbf{M a z e r ~ d a m ~}^{3}$ & & 8 \\
\hline$\tau_{\mathrm{c}}[\mathrm{Pa}]$ & 150 & $1.3 * 10^{-4}$ \\
$\mathrm{C}_{\mathrm{e}}[\mathrm{s} / \mathrm{m}]$ & $0.4^{*} 10^{-6}$ & 3.9 \\
$\mathrm{I}_{\mathrm{e}}$ & 6.4 & 1700 \\
$\rho_{\mathrm{d}}\left[\mathrm{kg} / \mathrm{m}^{3}\right]$ & 1700 & $7.8 * 10^{-2}$ \\
$\mathrm{~K}_{\mathrm{d}}[\mathrm{cm} / \mathrm{N} . \mathrm{s}]$ & $2.3^{*} 10^{-4}$ & \\
\hline
\end{tabular}

Moulay Boucheta dam

$\tau_{\mathrm{c}}[\mathrm{Pa}]$

100 

$\mathrm{C}_{\mathrm{e}}[\mathrm{s} / \mathrm{m}]$
$1.0^{*} 10^{-6}$
$0.3 * 10^{-5}$
$\mathrm{I}_{\mathrm{e}}$
6.0
5.5
$\rho_{\mathrm{d}}\left[\mathrm{kg} / \mathrm{m}^{3}\right]$
1700
1700
$\mathrm{K}_{\mathrm{d}}\left[\mathrm{cm}^{3} / \mathrm{N} . \mathrm{s}\right]$
$5.9 * 10^{-4}$
$1.7 * 10^{-3}$

In order to address the vulnerability of tested soils with regard to internal erosion, the results above (Table 3) have been used for soil classification based on Wan and Fell (2002) guidelines, indicating how long the soil resists to erosion before and after desiccation. Results (Figure 14) indicated that before desiccation the core soil showed an extremely slow erosion for all three dams, while after desiccation a moderately rapid erosion has provided for Mazer Dam and moderately slow erosion for Koudiat El Garn dam and a slow erosion for Moulay Boucheta dam. Therefore, even though the core soil is stable (low vulnerability to erosion) at optimum water content, after desiccation the soil becomes very sensitive to erosion especially for Mazer dam. However, it has been observed for Moulay Boucheta dam that even though soil erodibility has been quite extremely slow, a slight evolution toward very slow erosion has been noted after desiccation.

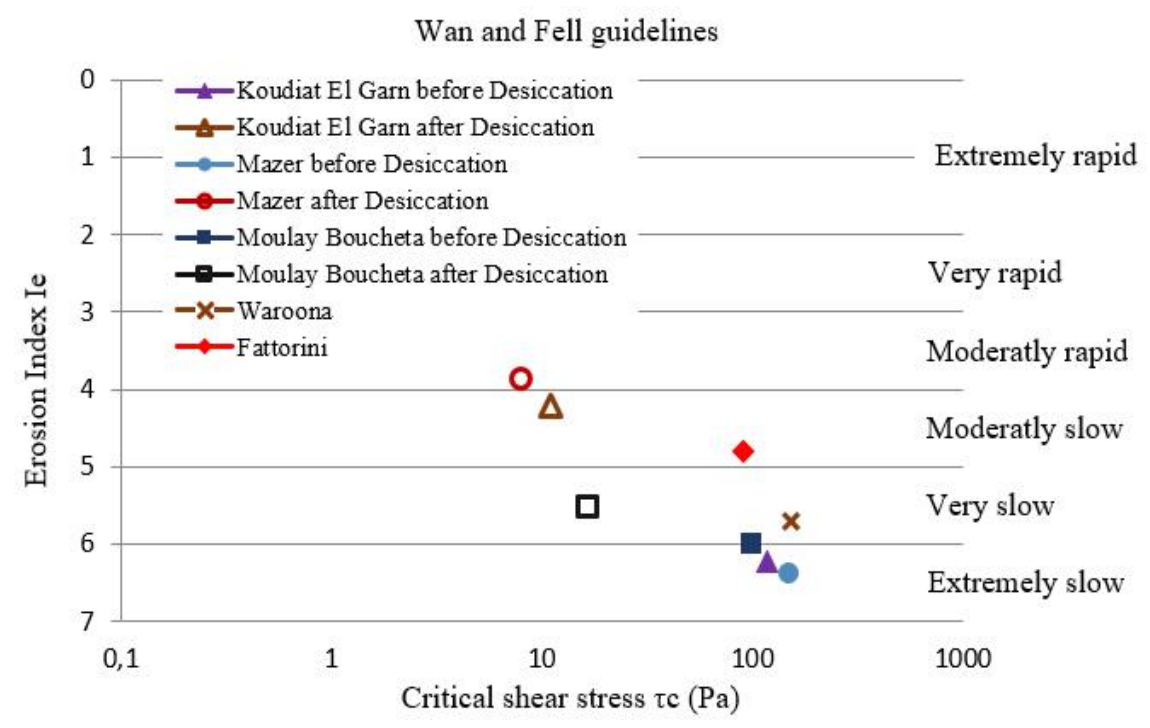

Figure 14. Assessment of soil classification according to Wan and Fell (2002) guidelines

In order to check the relevance of previous susceptibility assessment of the core material, a second classification method has been used by means of the diagram provided by Hanson and Simon (2001) criterion. To perform this classification, the parameters used to characterize soil resistance to erosion reported in Table 3 have been used. It has been found from these guidelines (Figure 15) that the core soils are very resistant at optimum water content, but once desiccation was reached the soils became moderately resistant for Koudiat El Garn and Mazer 
dams, and resistant for Moulay Boucheta dam which showed a strong resistance against erosion either before or after desiccation. Thus, the comparison of the classifications obtained from the two guidelines underlines the consistency of the provided results, indicating that investigated core soil remained less vulnerable to erosion if its moisture is hold to the optimal value, but became susceptible to erosion after a strong drying (desiccation). However, Hanson guidelines are less conservative as regards to the soil resistance against erosion after desiccation. From the comparison of the measurements carried out on the amount of the eroded solid mass, whether before or after desiccation for core soil dams, we were able to demonstrate a consistency of the classifications obtained on erosion susceptibility.

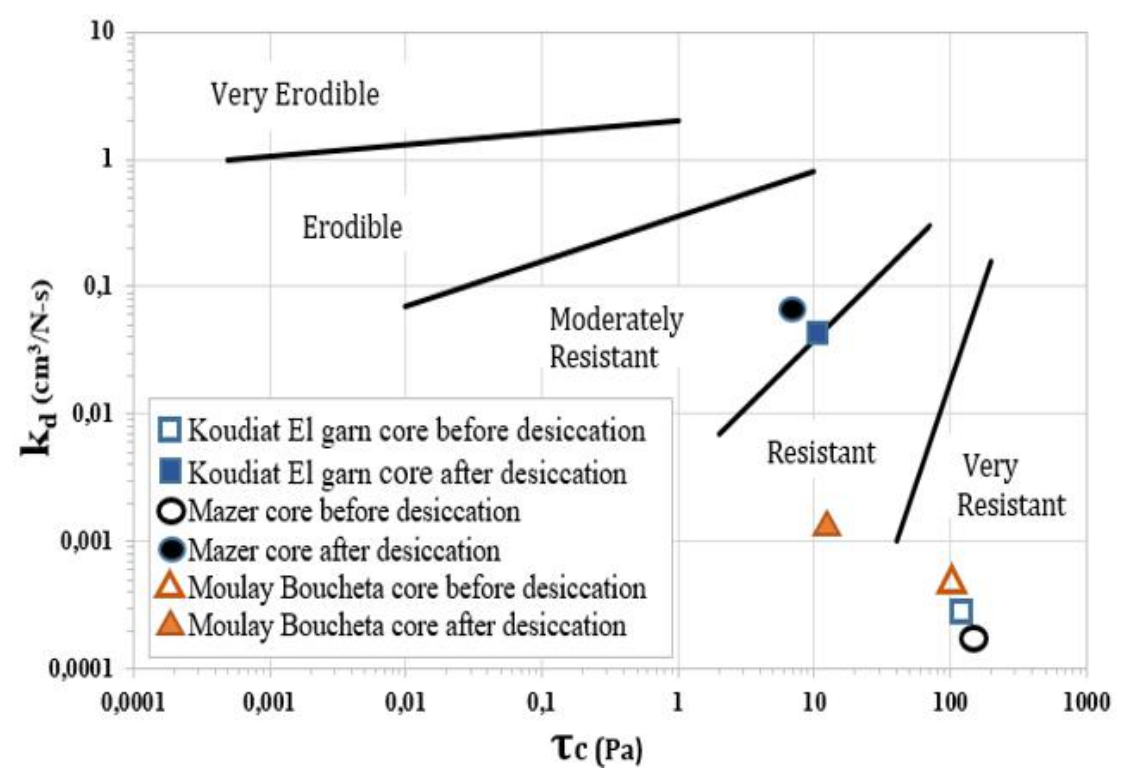

Figure 15. Erodibility classification of tested soil according to Hanson and Simon (2001) diagram

Both guidelines indicate the severe negative effect of the drought on erosion susceptibility of dam core in arid area and core soil involving more fines suffered less internal erosion. So, through these classifications using engineering guidelines our results will allow to predict the behavior of core soil after a severe drought, especially for the similar kind of soils that those tested. The phenomenon of desiccation which remains less investigated, can lead to core soil susceptibility to erosion after the formation of cracks. The HET remains the appropriate test devoted to simulate the process. Therefore, presented results will be able to constitute a contribution to the engineering application to the earthen dam safety against internal erosion.

\section{Concluding remarks}

Hole erosion tests have been conducted on samples collected from base soil (core) of three 
dams (embankment and zoned dams) in Morocco aimed to assess their vulnerability to erosion, especially after drying. So, if the rainfall rate continues to decrease in dam area, the drought likelihood increases and can threaten dam's stability. In laboratory tests, the drastic water content reduction has been achieved in order to simulate the behavior of dams during drought, highlighting the effect of core soil desiccation on dam hydraulic stability. Thus, a new reservoir filling may lead to more core susceptibility to internal erosion, ultimately leading to the structure collapse. It has been showed through the identification of the effectiveness of the tested soil that dams core soils are resistant to erosion when compacted and hold at the optimum water content. Nevertheless, it has been demonstrated through lowering water content up to desiccation that core soil became extremely susceptible to erosion. Once the drying stage was reached, the rise of cracks leads to a brutal impact on the efficiency of the soils against erosion. From obtained results, we can expect a serious degradation of soil resistance against erosion if water content decreases drastically. The three core soils tested showed different behavior as regards to desiccation. Even though Mazer soil core suffered the weakest erosion before drying, it provided the most susceptibility to erosion after desiccation, as well as Koudiat El-Garn dam, owing likely to the lower clay content involved and the weak soil plasticity. Moulay-Boucheta core soil was the most resistant against erosion after desiccation owing to its high plasticity and larger fines content. Overall, both guidelines indicate the severe negative effect of the drought on erosion susceptibility of dam core in arid area and core soil involving more fines suffered less internal erosion. Recommendation to take the core soil at a minimal water content not far from the optimal value in the dry side is essential for dam structures (be ensured that the desiccation state in earthen dams core can-not be reached during very long dry seasons), and to protect the core against hydraulic fracturing (arching zones in the embankment) filter efficiency is recommended.

\section{REFERENCES}

[1] Archer A and Ng CWW (2018) Effects of temperature and relative humidity on a clay embankment: centrifuge modelling. Géotechnique letters 8(2):138-143, https//doi.org/10.1680/jgele.18.00002.

[2] ASTM D-2487-17 (2017) Standard practice for classification of soils for engineering purposes, unified soil classification system. American Society for Testing and Materials, West Conshohocken. 
[3] Caldeira L (2019) Internal Erosion in Dams: Studies and Rehabilitation. International Journal of Civil Engineering 17(1):457-471, https//doi.org/10.1007/s40999-018-0329-5.

[4] Chang DS and Zhang LM (2013). Critical hydraulic gradients of internal erosion under complex stress states. J. Geotech. Geo-environ. Eng. 139(9):1454-1467, https//doi.org/10.1061/(ASCE)GT.1943-5606.0000871.

[5] Coulson, B. (2003). The effect of fine fissuring of clay on the stability of flood defence embankments. MEng Final Year Report, University of Durham.

[6] Cui YF, Gao YB and Ferber V (2010). Simulating the water content and temperature changes in an experimental embankment using meteorological data. Eng. Geol. 114(1): 456-471.

[7] Cui YF, Zhou XJ and Guo CX (2017) Experimental study on the moving characteristics of fine grains in wide grading unconsolidated soil under heavy rainfall. Journal of Mountain Science. 14(3):417-431, https//doi.org/10.1007/s11629-016-4303-x

[8] Dickson A (2004) Investigation into the effect of fine fissuring of clay on the stability of flood defence embankments. MEng Final Year Report, University of Durham.

[9] Dijkstra TA and Dixon N (2010) Climate change and slope stability in the UK: challenges and approaches. Quarterly Journal of Engineering Geology and Hydrogeology 43(1):371-385, https//doi.org/10.1144/1470-9236/09-036.

[10] Dyer M, Utili S and Zielinski M (2007) The influence of desiccation fine fissuring on the stability of flood embankments. FRMRC Research Report UR11.

[11] Hanson GJ and Simon A (2001) Erodibility of cohesive streambeds in the loess area of the midwestern. USA Hydrological Processes 15(1):23-38.

[12] ICOLD (2013) Internal erosion Processes and Engineering Assessment. In COLD Bulletin on Internal Erosion of Existing Dams, levees and dikes, and their foundations, vol.1, ICOLD, Paris, France.

[13] Indraratna B, Nguyen VT and Rujikiatkamjorn C (2011) Assessing the Potential of Internal Erosion and Suffusion of Granular Soils. J. Geotech. Geo-environ. Eng. 137(5): 550-554, https//doi.org/10.1061/(ASCE)GT.1943-5606.0000447

[14] Jalil A, Benamar A and Ebn Touhami M (2019) Erosion - filtration analysis for assessing hydraulic instability of dams in Morocco and global warming effect. 2nd International Conference on EGRWSE, University of Illinois-Chicago. In: Reddy KR, Agnihotri AK, Yukselen-Aksoy Y, Dubey BK and Bansal A (Ed.) Sustainable Environment and Infrastructure. Lecture Notes in Civil Engineering, vol. 90 Springer, Cham. https//doi.org/10.1007/978-3-030-51354-2_41. 
[15] Jalil A, Benamar A and Ebn Touhami M (2020) Assessment of a dam vulnerability to internal erosion due to climate change in Morocco. Innovative Infrastructure Solutions, 5(2), https//doi.org/10.1007/s41062-020-00297-9.

[16] Jalil A, Benamar A and Ebn Touhami M (2021) Investigation of internal erosion susceptibility of core soil from three dams. Journal of Civil Engineering and Construction 10(2):59-68, https//doi.org/10.32732/jcec.2021.10.2.59

[17] Lim S (2006) Experimental investigations of erosion in variably saturated clays. Ph-D thesis report, University of New South Wales, Australia.

[18] MacRobert CJ, Day PW and Luker I (2019) Strength changes during internal erosion of gap-graded soils. Proceedings of the Institution of Civil Engineers - Geotechnical Engineering 172(4):331-343, https://doi.org/10.1680/jgeen.18.00064

[19] Marnette E, Schuren C, Van de Brink K, Glew ND, Dyer M, Romero EJ (Ed.) and Cui YJ (Ed.) (2005) Further tests on the fissuring of clay fill at thorngumbald food embankment. In Advanced Experimental Unsaturated Soil Mechanics, 501-504.

[20] Morris PH, Graham J and Williams DJ (1992) Cracking in drying soils. Canadian Geotechnical Journal 29(2):263-277.

[21] Reddi LN, Lee IM and Bonala MVS (2000) Comparison of Internal and Surface Erosion Using Flow Pump Tests on a Sand-Kaolinite Mixture. Geotechnical Testing Journal, GTJODJ 23(1):116-122.

[22] Salari M, Akhtarpour A and Ekramifard A (2018) Hydraulic fracturing: a main cause of initiating internal erosion in a high earth-rock fill dam. International Journal of Geotechnical Engineering 15(2):207-219, https//doi.org/10.1080/19386362.2018.1500122.

[23] Sherard JL (1953) Influence of soil properties and construction methods on the performance of homogeneous earth. U.S. Dept. of the Interior, Office of Reclamation, Design and Construction Division.

[24] Wan CF and Fell R (2002) Investigation of internal erosion and piping of soils in embankment dams by the slot erosion test and the hole erosion test. The Univ. of New South Wales, Sydney, Australia, UNICIV Rep. R-412.

[25] Wilson GV, Periketi RK, Fox GA, Dabney SM, Shields FD and Cullum RF (2007) Soil properties controlling seepage erosion contributions to streambank failure. Earth Surf. Process. Landforms 32(1):447-459, https://doi.org/10.1002/esp.1405 
[26] Zeng H, Tang Cs, Cheng Q, Inyang HI, Rong Dz, Lin L and Shi B (2019) Coupling effects of interfacial friction and layer thickness on soil desiccation cracking behavior. Eng. Geol. 260(1):105-220, https://doi:10.1016/j.enggeo.2019.105220. 